interval of time and this became the predominant view. There was, of course, a celebrated dispute between the Cartesians and Leibnizians on the question whether $m v$ or $m v^{2}$ were the more fundamental entity to be employed in a universal conservation law. It lasted more than half a century, until brought to a close by D'Alembert in 1743. He showed that the dispute was in effect merely one concerning the best choice of co-ordinates, for. $P t$ leads to the Cartesian $m v$ whereas $P s$ leads to $m v^{2}$. The eccentric Cavendish seems to have reasoned out th? consequences of the conservation of kinetic and potential energy in general terms. This, at least, is the view of Sir Edward Thorpe, who edited Cavendish's unpublished papers.

During the eighteenth century it became evident that physics could not be unified on kinetics; the identities of mechanics had to be traced in other phenomena. In 1787 Rumford (Benjamin Thompson) showed that there was no significant change in weight when water turned to ice; the hypothesis of the material nature of heat (and light) had soon to be given up. Text-books of physics commonly deal with these matters, though, so far as I know, they never give any experimental details for Davy's melting of ice by friction, an experiment which, on the face of it, has few claims to serious consideration ${ }^{8}$.

${ }^{1}$ NATURE, 149, 688 (1942)

2 "Memoir of James Prescott Joule", 17 (1892).

" "Oeuvres Complètes", 16, 50-64.

“"Oeuvres Complètes", 16, 414.

"Oeuvres Complètes", 18, 259

'" "Oeuvres Complètes", 18, 554.

'NATURE, 148, 511 (1940)

${ }^{8}$ Andrade, E. N. da C., NatoRe, 135, 359 (1935).

\section{CO-OPERATIVE SYSTEMS IN EUROPEAN AGRICULTURE}

$\mathrm{A}$ YEAR ago the Division for the Social and International Relations of Science of the British Association held a conference on post-war European agriculture, which formed one of a series of conferences on post-war reconstruction. Since then a good deal of work has been done on the problems of agricultural reconstruction both by the governments of Allied countries in London and by inter-allied bodies like the Leith-Ross Committee. It has become clear that important as will be the material help which can be brought into the liberated countries from outsidethe seeds, implements, fertilizers, even livestock, which will be required to restore their impoverished farms-the effectiveness of such aid will depend, both in the period of relief and the longer period of reconstruction, on the effectiveness of internal organization and the extent to which agriculture is integrated technically, economically and socially.

It was with this consideration in mind that the British Association called a second conference on April 16 and 17,1943 , to discuss the most widespread of the methods of agricultural integration in Europe, the co-operative system. The conference was welcomed by Sir Richard Gregory on behalf of the British Association. Sir John Russell, in his opening address, recalled how speakers at the previous conference, confronted with the agricultural alternatives of national self-sufficiency or a high standard of living, and of large or small farms, had, almost without exception, declared for the small farm and a high standard of living, especially of nutrition. The present conference accepted, and would have to deal with, the consequences of that decision. The disadvantage of the small farm is the overwhelmingly hard labour it demands, which bears particularly heavily upon the women. The small farm lacks machinery to lighten that toil, it lacks the capital needed to carry the farmer through the long cycle of agricultural production, and it is frequently burdened with debt. Methods of marketing are primitive and wasteful. It is the testimony of practical men that co-operation has provided a remedy for these evils. It has in addition given a technical training to the small farmer, raising his standards of cultivation and putting him in touch with modern knowledge.

The first session was devoted to the experience of Western Europe, beginning with the British Isles. Mr. Hewitt, himself a farmer and the chairman of a farmers' co-operative society in the west of England, took the co-operative supply of agricultural requirements as his main theme. He showed the large part which agricultural co-operative societies play in the handling of requirements such as seeds and feeding stuffs, grown by one set of farmers and used by another, and instanced, in particular, the distribution of the famous Aberystwyth strains of grasses and clovers and of 'once grown' seed potatoes. He looked forward to the end of the War and the urgent call from the devastated countries of Europe for agricultural requirements and supplies of all kinds, which it would be the great privilege and very pleasant duty of British farmers to meet with abundant supplies of the best qualities of seeds, seed corn and seed potatoes.

The application of co-operation to the problems of the Scottish crofters, the nearest approach to a peasantry to be found in the United Kingdom, was described by Mr. C. J. M. Cadzow, secretary of the Scottish Agricultural Organisation Society. He described how, following on the widespread failure of the crofters' potato crop in 1938, his Society had undertaken the distribution of seeds and fertilizers through the clerks to seven hundred grazing or township committees. All requirements were those recommended by the agricultural colleges as suitable to the district concerned. The Society had also arranged for the sale of the crofters' wool. The co-operative movement in Ireland, the remarkable pioneer work of Horace Plunkett and his associates guided by the formula "Better farming, better business, better living", and the world-wide influence of the movement, great out of proportion to its material achievements, were described by Miss Margaret Digby.

M. André Dulin, of the French National Committee, described the part played by agricultural co-operation in France in the provision of credit, both individual and collective, in insurance, the provision of agricultural requirements and in the processing and marketing of agricultural produce. $\mathrm{He}_{\Theta}$ looked forward to the position of French agriculture at the end of the War, with soil impoverished and overmun by weeds, livestock and machinery diminished and labour reduced, since returning prisoners would be physically unfit to make much immediate contribution. It was likely also that experience of the failure of all the boasted reorganization of agriculture by the Vichy Government would have bred pessimism and suspicion of all State regulation. On the other hand, sheer necessity has brought much informal co-operation in the use of implements and transport 
facilities. The hope of the future lay in the professional reorganization of agriculture on the lines of voluntary co-operation.

M. Borremans, agricultural attaché to the Belgian Embassy, concluded the session with a sketch of agricultural co-operation in Belgium under the leadership of the well-known Boerenbond Belge, with its simultaneous concern for technical advance and instruction, social welfare and economic prosperity.

The second session was devoted to the northern countries lying about the North Sea and the Baltic, all having in common a strong dairy element in their co-operative economy. The chair was taken by Dr. C. R. Fay, reader in economic history in the University of Cambridge. Agriculture in these countries, he said, is based on the family farm, but it is not a peasant economy ; it is the family farm, commercialized, mechanized and specialized, and the conditions of its success are two: State guardianship of the land unit, which can neither be merged in the large estate nor fragmented into the dwarf holding, and co-operative economics. Adjustment to an export market is not the secret of Scandinavian success in co-operative organization. It must be sought rather in the high intelligence of the participants, based on high education, in democratic feeling, and in the integrated and dynamic character of the movement. All this can be seen not only in the countries represented at the conference, but also in Finland and Iceland.

Mr. P. A. Moltesen, agricultural attaché to the Danish Legation, described the spontaneous origin of Danish co-operation and its specialized character, with one function for each type of society, and its corollary, multiple membership by each farmer, and the final linking of all societies in a national federation which exerts considerable influence upon the economic policy of the country. Mr. S. Krolikowski (Poland) spoke of co-operation as the means by which the peasant farm can effect the difficult transition between self-sufficiency and participation in a capitalistic economy, and can combine individual land ownership and cultivation with collective action in purchase, manufacture and sale. Co-operation, again, is the best channel of technical instruction for the farmer and the means of stimulating him to adopt more scientific methods. Before the War, 50,000 students were accommodated in co-operative schools. During the War, though their educational work has ceased, there is reason to believe that the agricultural trading co-operatives are still in use and developing, since they were too strong for the enemy to destroy without an adverse effect on the production-level. After the War their part would grow still more, in the organization of food supplies and the replanning of agricultural economy. Mr. Fjelstad, minister in the Norwegian Cabinet, sketched the development of co-operation in Norway both in farming and forestry, where co-operative insurance and the organization of a fireguard service have saved considerable national assets from destruction. He described how the already developed co-operative dairy system enabled the Norwegian milk marketing board to be organized from the bottom up and not, as in Great Britain, from the top downwards. Mr. Gerritzen, agricultural attaché to the Netherlands Embassy, spoke of the many-sided co-operative organization of his country, the part it has played in the development of the famous market garden industry of the Netherlands, and its bold and successful entry into the beet sugar industry. In the discussion, other speakers referred to the co-operative movements of the Baltic States and Iceland.

A further session of the Conference was devoted to a somewhat different aspect of the immediate postwar problem, the emergency distribution of food. In this the farmers and their organization have a part to play, since every country must rely fundamentally on the food which can be produced within its own borders. But in the first fow months of liberation every European country will be dependent on emergency supplies hurried into its towns and industrial areas-sometimes even into its rural areas-from overseas. These supplies will have to be distributed, as will those delivered from the country as soon as normal transport has begun to work. Distribution in such emergency conditions may not be easy to improvise and the normal channels of trade may be blocked or unsuitable. In these circumstances, the existence of a consumers' co-operative movement, whether catering mainly for the industrial population, as in Great Britain, or of a rural character as in many Continental countries, may well be of the highest value to the relief administrator or newly restored national government. It has the machinery of distribution, it serves public ends and enjoys the confidence of its members.

Mr. J. MeFadyen, of the Co-operative Whólesale Society, opened the session with an account of the experience of the British co-operative movement in distributing foodstuffs in periods and areas of heavy bombing. He described the way in which neighbouring societies have come to one another's assistance. In one case where all the bakeries of a city were temporarily put out of action, nearly two thirds of the necessary supplies were sent in from the co-operative bakeries of other towns and distributed both to co-operative members and others. Repairs to co-operative premises anywhere were the immediate concern of a central C.W.S. building department. Dispersal of essential stocks is made easy by the wide network of co-operative societies and the mutual understanding which exists between them. This account of actual and recent experience was followed by a survey from Mr. R. A. Palmer, acting chairman of the International Co-operative Alliance, of the actual resources in productive and distributive machinery, as 'well as in membership, of the cooperative movements in Europe, resources which, in spite of the restrictive and in some cases even destructive action of the occupying enemy authorities, will, it is hoped, be available to those who have to administer the distribution of food in the first difficult weeks after liberation.

Precisely how difficult those weeks may be was made plain in an address by Mr. J. Kwapinsky, Minister of Social Welfare in the Polish Government, who described the appallingly low level of rations which have been in force in Poland for a long time past : rations of 600-800 calories daily for the Polish Christian population and of less than 300 calories for the Jewish populations, in both cases below minimum physiological need. Relief of the town populations of Poland would have to be given with all possible speed. The enemy has destroyed private trade, and controls food distribution largely through the prewar co-operative system, which is dominated but not destroyed. The supervision of food distribution in the post-war period will have to be transferred to the revived Polish local authorities, but for actual distribution in emergency circumstances, the co- 
operatives would be the most elastic system with the necessary commercial knowledge and storage and transport facilities. On their commercial efficiency in collecting home-grown food, in which agricultural co-operatives would also play their part, would depend in large measure the successful mastery of the 'black market'. On the efficient distribution of food from abroad would depend the speed of agricultural reconstruction, since no reconstruction could be attempted until such pheriomena as the reckless slaughter of livestock for food has ceased. These conclusions were reinforced on the administrative side by Mr. R. Kreisky, speaking for Czechoslovakia, and on the nutritional aspect of the problem by Dr. Magnus Pyke of the British Ministry of Food, who described the very interesting inquiry into nutritional conditions in an industrial suburb of Madrid, carried out by the Rockefeller Foundation in the summer of 1941. This, while access to occupied Europe was impossible, provided the best indication of the sort of conditions which are likely to be found among the liberated peoples. The main conclusion was that the fundamental condition was a shortage of calories rather than deficiency of any particular constituent. The diet was pitiably scanty but not grossly unbalanced.

At its last session, the conference returned to the agricultural and productive, rather than the distributive, aspect of co-operative organization, and considered the experience of countries in Eastern Europe, Czechoslovakia, Yugoslavia, Greece and the Soviet Union. Dr. Bicanic (Yugoslavia) looked beyond the organization of co-operation on the 'classic' pattern of local and voluntary association, already developed with a varying measure of success in the different regions of Yugoslavia before the War. He envisaged a type of co-operation which would embrace the entire village community, deriving from the old Slav principle of the 'Zadruga', or family group, which is still a living force. Such a village co-operative would not be a collective in the Russian sense, but it would carry out a complex of services usually divided among separate co-operative societies, local authorities or individuals, or in many rural communities wholly neglected. A movement in this direction was developing spontaneously before the War; the post-war task would be to foster and extend it. Mr. Hodza (Czechoslovakia) showed how the strength of the co-operative movement had been built up by voluntary effort in the days of Austrian and Hungarian rule, and how under the Republic it was able to take a leading place in national economy. Mr. Polychroniades (Greece) looked to the reconstruction of Greek agriculture and the raising of the peasants' standard of living through a much more extensive application of co-operative methods. Dr. Barou concluded the review of European experience with an account of the wholly different application of the co-operative principle in the Soviet Union, where collective ownership of land and collective application of labour have replaced the individual peasant farm and, with the increased size of the unit and the State control of banking and commerce, the ordinary economic functions of the co-operative have disappeared.

The final impression left by the Conference was of the strength, ubiquity and diversity of the co-operative movement in Europe, and of the extent to which it is, and will doubtless remain, the principal instru. ment of raising both the technique of European farming and the social conditions of the peasant.

\section{THE IMPERIAL INSTITUTE JUBILEE OF OPENING BY QUEEN VICTORIA}

\author{
By Dr. H. A. TEMPANY, C.M.G., C.B.E.
}

$\mathrm{O}^{\mathrm{s}}$ May 10 the Imperial Institute will have reached the fiftieth anniversary of its opening by Queen Victoria. In normal times such an event would doubtless have been marked by some public ceremony appropriate to the occasion, which possesses, in certain respects, a unique historical interest. Under war-time conditions this is precluded, of course, but at least the event warrants some examination in brief retrospect of the history of the Institute and the part which it has come to play in public affairs to-day.

The genesis of the Institute occurred in 1887, when its foundation as a memorial of the golden jubilee of Queen Victoria was undertaken. Its first president was the then Prince of Wales, afterwards Edward VII, under whose direct guidance the Institute was organized. It is, therefore, a relic of the zenith of the Victorian era, those spacious days when the political skies appeared serene and unclouded and there was scarcely more than a hint of the grievous troubles which were to assail the world during the ensuing half-century.

The general objects which the Institute was founded to fulfil were to promote the development of the British Empire and to foster relationships between its numerous component territories and the mother country. Specifically, it was intended to promote the development and utilization of the resources of the Empire, to foster new forms of production as well as the processing and marketing of Empire products, to collect and disseminate information concerning the Empire, its peoples and its products, and later it was instructed to advise on the availability and utilization of its raw materials for Imperial defence. Con. currently it was intended that it should collect samples and specimens of Empire products, and establish and maintain exhibition galleries open to the public, which would serve as an indication and a reminder of the character of the Empire and of the vast resources which it contained. It was also envisaged that the Institute should serve as a link between the various parts of the Empire and a focus and a meeting-place from which would emanate new projects and schemes in connexion with Imperial development.

The concept had at that time a certain novel grandeur, and, associated as it was with the immense and now almost legendary affection, esteem and veneration in which Queen Victoria was held, it made an immediate popular appeal; as a result the large sum-for those days-of $£ 400,000$ was raised from official and private sources to launch the project. Of this sum $£ 250,000$ was devoted to erecting the impressive building in South Kensington, in which it has ever since been housed; the remaining $£ 150,000$ was constituted into an endowment fund.

The first director was Sir Frederick Abel; he was succeeded in 1903 by Prof. (afterwards Sir Wyndham) Dunstan, who retired in 1925 and was succeeded by Sir William Furse. The present director, Sir Harry Lindsay, succeeded Sir William Furse in 1934.

After its inauguration the wave of enthusiasm evaporated, while the available revenue from the endowment fund and other sources proved inadequate 